\title{
Piety and Conflict in the Early Reformation: Introduction
}

\author{
ANDREW GOW \\ University of Alberta \\ ROBERT J. BAST \\ University of Tennessee
}

B an unspoken consensus based, one suspects, on centuries of myth-
based commemorations, 2017 will be celebrated as the five-hundredth anniversary not merely of Luther's ninety-five theses but of the Reformation as a whole. ${ }^{1}$ Leaving aside the now hoary and largely settled debates about whether or not Luther ever actually posted any theses on the door of the castle church at Wittenberg on 31 October 1517, or if he did, what he meant to accomplish, we turn our attention to the early Reformation period-not to celebrate 1517, but because we think there are more important questions requiring investigation in that early period.

Long considered by Protestant church historians and many others as the decisive break not merely with "Rome" but with arbitrary authority tout court, "the Reformation" continues to figure in textbooks, encyclopedia articles, works of political punditry, and popular entertainment as a kind of turning point to liberal modernity. ${ }^{2}$ The good citizens of "Lutherstadt Wittenberg," not to be begrudged an opportunity for civic boosterism and revenue

1. Charles Zika has traced the origins of seventeenth-year centenary commemorations in his piece "The Reformation Jubilee of 1617: Appropriating the Past through Centenary Celebration," in Exorcising Our Demons (Leiden: Brill, 2003), 197-236. Scott Berg has recently addressed the 1817 anniversary in “"The Lord Has Done Great Things for Us': The 1817 Reformation Celebrations and the End of the Counter-Reformation in the Habsburg Lands," Central European History 49 (2016): 69-92. In his book Ecumenism, Memory, and German Nationalism, 1817-1917 (Syracuse: Syracuse University Press, 2014), Stan Landry addresses the last two Reformation centenaries.

2. See Alec Ryrie, “Moderation, Modernity and the Reformation," Past and Present 223.1 (2014): 271-82. Heiko Oberman called this "the founding myth of international Protestantism: the notion that Luther's call for liberation from the Babylonian captivity [of the church] led to a wondrous escape from Roman papal tyranny and a passage out of the dark Middle Ages." The Two Reformations: The Journey from the Last Days to the New World, ed. Donald Weinstein (New Haven and London: Yale University Press, 2003), xvi. 
enhancement, have been at it for most of the year, promoting Wittenberg as the matrix for the transformation of German language, art, music, even its concept of freedom itself. ${ }^{3}$ This view has been challenged and all but banished from specialized academic circles, though its ghost lives on in many forms, largely in popular culture and the retail politics of centrist liberal parties. However, it is also somehow unkillable even within some parts of the academy. Thomas Kaufmann, professor of recent Protestant church history at one of Lutheranism's traditional intellectual bastions in Germany, the University of Göttingen, continues to defend Luther's German Bible translation, for example, as a general "theological and cultural breakthrough." "Breakthrough" (Durchbruch) belongs to the language of scientific discovery or truth-finding, not of analysis or even description. It posits progress from error or ignorance to truth or knowledge. This assertion is more theological and triumphalist than historical and analytic. Kaufmann and many other Protestant church historians continue to insist on the epochal nature of Luther's thought and work, and thus to hold firm against the kind of relativizing judgment that could be heard as early as the 1980s in G. R. Elton's characterization of Luther as merely the reformer of the German lands. ${ }^{5}$

3. "Denn was vor 500 Jahren in Wittenberg begann, prägt unser Leben bis heute - unsere Sprache, die Kunst und Musik, unseren Freiheitsbegriff." Wittenberg Lutherstadt ("Die Stadt der Reformation"), accessed 2 June 2017, http://www.wittenberg.de/htmlsite/index.php?menuid=3\&topmenu=3.

4. Thomas Kaufmann, "Vorreformatorische Laienbibel und reformatorisches Evangelium," Zeitschrift für Theologie und Kirche 101 (2004): 138-74. For an alternative point of view, see Volker Leppin, "Biblia, das ist die ganze Heilige Schrift deutsch: Luthers Bibelübersetzung zwischen Sakralität und Profanität," in Protestantismus und deutsche Literatur, ed. Jan Rohls and Gunther Wenz (Göttingen: Vandenhoeck und Ruprecht, 2004), 13-26, and Andrew C. Gow, “The Contested History of a Book: The German Bible of the Later Middle Ages and Reformation in Legend, Ideology, and Scholarship," Journal of Hebrew Scriptures 9.13 (2009): 1-37. The assault on this kind of "romanticism" reaches deep into the last century: see Thomas A. Brady, Jr., “'The Social History of the Reformation' between 'Romantic Idealism' and 'Sociologism': A Reply,' Stadtbürgertum und Adel in der Reformation: Studien zur Sozialgeschichte der Reformation in England und Deutschland, ed. Wolfgang Mommsen, Peter Alter, and R. Scribner (Stuttgart: Klett-Cotta, 1979), esp. 41.

5. G. R. Elton, "Die europäische Reformation. Mit oder ohne Luther?” in Elton's Studies in Tudor and Stuart Politics and Government, IV: Papers and Reviews 1983-1990 (Cambridge: Cambridge University Press, 1992), 246-63, 262. Originally in Martin Luther: Probleme seiner Zeit, ed. Volker Press and Dieter Stievermann (Stuttgart: Klett-Cotta, 1986), 43-57, and cited below by Tom Scott. 
Presented with the opportunity to edit a special issue to mark the fivehundredth anniversary of the events of 1517, we have chosen a different emphasis, one that might serve as a counterbalance to those accounts that, consciously or not, reinforce Luther's own lamentable tendency to see the Reformation as his, protestations to the contrary notwithstanding. To that end, we have chosen to focus on smaller stories that underscore the contentious, confused, and undetermined moments that marked the Reformation in its first generation. This is hardly an arbitrary choice, however, for the central events of 1517 emerged from the nexus between piety and conflict, evident already in Luther's attack on the indulgence system and intensified by the church's counterattack. ${ }^{6}$ This special issue has been especially inspired by the work of Tom Scott, who recently urged a return to the study of the early Reformation, still rich in overlooked sources and unexplored episodes highlighting the "astonishing mixture of radical religious disenchantment and straightforward thuggery" that marked the attempt of countless men and women to realize the dreams and desires awakened by events that began in $1517 .^{7}$

Scott has been instrumental in the reshaping of Reformation history from a branch of confessional polemics, both theological and historical, into a branch of social history. As he has pointed out in his career-spanning effort to historicize the Reformation, the processes underway well before $1517 \mathrm{did}$ not suddenly culminate or cease at that point; the Reformation itself was much, much more than just a theological event. Older generations of church historians, Protestant and Catholic, naturally emphasized theological conflict. But to secular historians, that emphasis required correction. From the 1960s on, British and American early modernists in particular worked to build a new social history of the Reformation era and process, one that did not place theological disputes and texts in the centre of the action and that attempted, ultimately, to place the lives, actions, concerns, suffering, and aspirations of ordinary people at the centre of their work—rather than simply add a framing

6. "The [ninety-five] theses did not contain a full theological program; rather, Luther was radicalized by the opposition he encountered, and the arguments and attacks of others made him develop his theology and pursue his ideas further." Lyndal Roper, Martin Luther: Renegade and Prophet (New York: Random House, 2016), xxiii.

7. Tom Scott, "The Early Reformation in Germany between Deconstruction and Reconstruction," in The Early Reformation in Germany: Between Secular Impact and Radical Vision (Farnham: Ashgate, 2013), $7-30,30$. 
section on how common people got through the Reformation (as some more traditional camps attempted to do). In doing so, some scholars took ideological paths (e.g., the East German "early bourgeois revolution") that have not aged especially well. Others placed the Reformation into the political matrix of a more traditional variety of history-writing embedded in the priorities and categories of the nation-state, such as the West German "confessionalization" school led by Heinz Schilling and Wolfgang Reinhard, or the Sonderweg thesis that saw the empire's "arrested development" (failure to become a "western" nation-state after the model of France and England) as the causal nexus for the Reformation and all later developments in Germany history. Some scholars followed older paths in attempts to reach new goals, such as Heiko Oberman's pursuit of a "social history of ideas." Others have more recently addressed the issue of how peasants, craft workers, petty guildsmen, and other ordinary folk experienced the Reformation (e.g., Susan Karant-Nunn's work on ritual and on emotion, ${ }^{8}$ or Robert Christman's history of the Reformation among miners in the Duchy of Mansfeld ${ }^{9}$ ). And this is the level at which the shoe-leather hit the road, with both overt conflict and physical violence between individuals and groups structuring daily life and deciding outcomes in local contexts.

The numerical and cultural predominance in Protestant scholarship of Lutherans would make Luther into the initiator of something that later came to be called "the Reformation," and placed the legendary posting of the famous ninety-five theses on a door to the castle church at Wittenberg on 31 October 1517, with Luther himself at the headwaters of that "movement." 10 Yet during its earliest phases, "the Reformation" was never just Luther's. Many people wanted things from it that established powers were not about to surrender just for the asking. Piety and conflict went hand-in-hand for that reason (and others), even as Luther himself eschewed (most) physical violence and then strategically distanced himself from the peasant revolts. If anything, the later establishment of Lutheran state churches recast the violence and radical dissent

8. The Reformation of Ritual: An Interpretation of Early Modern Germany (London and New York: Routledge, 1997); The Reformation of Feeling: Shaping the Religious Emotions in Early Modern Germany (Oxford and New York: Oxford University Press, 2010).

9. Doctrinal Controversy and Lay Religiosity in Late Reformation Germany: The Case of Mansfeld (Leiden: Brill, 2011).

10. While the year 2017 is the occasion for this collection, the editors and contributors take issue with the confessional chronology that places the beginning of "the Reformation" in 1517. 
that characterized the late 1510s and 1520s in the German lands as aberrant, making Luther's movement ex post facto the hallmark of the "real" (and not, for example, the radical) Reformation. Yet it should be amply clear that no one knew, in 1520, which way things were going to turn, and that we have every reason to see violent iconoclasm, riots in the town square, or the Peasants' War as just as integral to the reforming movement as Luther's ninety-five theses or his influential early pamphlets.

While formulating this issue, we invited papers on a variety of subjects relevant to our theme, including though not limited to anticlericalism, communalism, iconoclasm, imperial/national reform programs, pamphleteering, the role of women, workers, and others outside the traditional privileged elites, and finally, resistance to incipient Protestantism by those loyal to the "old faith." We received a wide range of papers, most of them focusing on the primary and obvious matrix of the Evangelical movement beyond Wittenberg: namely, in the richly fragmented landscapes of the southern ("upper") German lands. The most obvious element that these latter have in common-other than the relative visibility of ordinary people through the well-preserved archives of this region-is the issue of how religious disenchantment and conflict coalesced at the level of the common people. A second thread common to several papers is Anabaptism. Both it and the peasant rebellions were rooted in radical religious disenchantment. While some varieties of Anabaptism (especially later ones) would be pacifist, early Anabaptists were also capable of something akin to organized thuggery (e.g., riots; Münster) - and both movements were met by the authorities in most cases with something not much short of official thuggery.

Jonathan Green sets the stage with his paper on the popular apocalyptic tone of the Extract of Various Prophecies (Auszug etlicher Practica und Prophezeiungen), the most popular prophetic pamphlet in Germany in the decade between 1516 and 1525. Green argues that this text, which reordered elements of the wildly popular earlier works of Lichtenberger and Grüneck into a coherent apocalyptic prognostication, helped create and shape an audience for popular prophetic preaching about the impending violent End Times in the early German Reformation. Johannes Wolfart insists, in his reconsideration of the Reformation at Lindau, that if we take the entire territory under the control of the city council into consideration (and not just the socially rather homogeneous island-city itself), the Reformation was not relatively peaceful, nor was the social situation that preceded it relatively peaceful and 
harmonious, the arguments of Bernd Moeller to the contrary. Wolfart argues for a much more conflictual model of Reformation, based on a much more conflictual model of Lindau society in general. Geoff Dipple makes a strong case that neighbouring Constance executed the Anabaptist Ludwig Hätzer as much for heresy as for the adultery of which he was formally convicted, the two crimes having shared a bed, as it were, since the 1233 bull Vox in Rama that associated heresy with sexual deviance. His religious disenchantment either led to or licensed behaviour intolerable to civic authorities, and disentangling his reputation for "thug life" from his theology would have been as moot as it was irrelevant. Robert Bast uses previously overlooked pamphlets to demonstrate that the poor weaver Utz Richsner developed and promoted the ideology that contributed to the social and religious unrest culminating in the violent but unsuccessful Evangelical uprising at Augsburg on behalf of the Franciscan preacher Johann Schilling in 1524. Henry Suderman illustrates Münsterite Anabaptists' attempts to wrench the gates of the old faith from its hinges using an exceptionally charismatic mixture of sophisticated theology, performance, and persuasion with authoritarian violence in the service of a place-centric iconoclasm directed against the (church) buildings and places of the "old faith" at Münster. Christopher Ocker explores the fate of a female landowner caught between Anabaptism, the aftermath of the Peasants' War, and the outright thuggery of a male relative who attempted to steal her inheritance (and nearly succeeded, by sheer bluster and violence) in the Lake Constance region in the mid-1520s. These papers demonstrate the working out of radical theological disenchantment via (popular) violence in the early years of the Reformation, as it arrived, in waves, in various parts of western Europe.

Scott's contribution to the present special issue points beyond the local and the parochial to the larger level of "Germany" and "national" consciousness, forged "agonistically" in conflict between rivals. This reminds us that there is an equally problematic and influential historiography at work at that level, in a kind of parallel to the Lutheran paradigm of the early "Reformation": that of the German Reformation. Again, Scott's work alerts us in a detailed way to the dangers of imposing categories after the fact on inchoate, disparate, and contingent events.

These papers draw attention to the early years of the various Evangelical movements. They point to the fragmentary nature both of our general knowledge of those periods and of the specific evidence available for each movement. They 
also highlight how the Lutheran paradigm of "the Reformation," concocted long after the events in question, continues to distort the field as a whole, as if only outcomes were significant-a winner's history, in short. If we are to obtain a better understanding of both the roots and the ramifications of the early Evangelical movements, we need to pay much more attention to the very local, the deeply situated-and the many alternatives to the magisterial and princely Reformations. 
